PRACE NAUKOWE UNIWERSYTETU EKONOMICZNEGO WE WROCLAWIU

\title{
Alina Piątyszek-Pych
}

Polskie Towarzystwo Ekonomiczne w Zielonej Górze

e-mail: alinapiatyszek@gmail.com

\section{POLITYKA WSPIERANIA KLASTRÓW W UNII EUROPEJSKIEJ}

\section{CLUSTER POLICY IN THE EUROPEAN UNION}

DOI: $10.15611 /$ pn.2017.477.20

Streszczenie: Celem artykułu jest przedstawienie polityki klastrowej realizowanej na poziomie Unii Europejskiej w latach 2006-2020. Uwaga skupiona została na działaniach podejmowanych przez Komisję Europejską. Osiągnięcie celu wymagało przeprowadzenia analizy literatury poświęconej klastrom oraz opracowań o charakterze praktycznym. Na początku przybliżono istotę i wybrane modele polityki klastrowej. Następnie przedstawiono zapisy najważniejszych dokumentów UE odnoszących się do gron. Dalej zaprezentowano wybrane dotychczasowe działania i inicjatywy Komisji na rzecz wspierania struktur klastrowych, a także założenia przyjęte w tym zakresie na bieżący okres programowania. Analiza aktywności podjętych na rzecz wspierania klastrów we Wspólnocie pozwala na wysunięcie wniosku, że skupiają się one na dwóch obszarach, tj. wzmacnianiu współpracy pomiędzy podmiotami oraz zarządzaniu klastrami. Działania te mają na celu zapewnienie lepszych warunków do powstania w UE większej liczby światowej klasy gron.

Słowa kluczowe: klastry, polityka klastrowa, Komisja Europejska, Unia Europejska.

Summary: The aim of this article is to present the cluster policy pursued at the level of the European Union in the years 2006-2020. The author focused on the actions taken by the European Commission. To achieve a goal, it was necessary to analyze the literature about clusters as well as studies of a practical nature. First, the essence of the cluster policy and the selected models were presented. Next, provisions of the most important documents of the EU relating to clusters were shown. Further past actions and initiatives of the Commission to support clusters and assumptions adopted in this respect for the current programming period were presented. The analysis of the actions taken to support clusters in the Community allows to draw the conclusion that it is possible to distinguish amongst them such ones which focus on strengthening cooperation between entities and such ones which focus on the cluster management. These activities aim at providing better conditions for the creation of a bigger number of the world class bunches in the EU.

Keywords: clusters, cluster policy, European Commission, European Union. 


\section{Wstęp}

Od lat 90. XX wieku rosnącym zainteresowaniem cieszy się koncepcja klastrów gospodarczych, którą spopularyzował M.E. Porter ${ }^{1}$. Zarówno sami przedsiębiorcy, jak i przedstawiciele jednostek samorządu terytorialnego (JST), instytucji otoczenia biznesu, rządów państw i organizacji międzynarodowych dostrzegają w strukturach klastrowych możliwości rozwoju pojedynczych przedsiębiorstw, a także podniesienia konkurencyjności i przyspieszenia rozwoju gospodarki lokalnej, regionalnej i krajowej, a nawet międzynarodowej. Doprowadziło to do wyłonienia koncepcji polityki rozwoju gospodarczego opartej na klastrach (CBP - Cluster Based Policy).

$\mathrm{W}$ tworzenie i wzrost gron angażują się w coraz większym stopniu organizacje międzynarodowe, takie jak OECD, Unia Europejska oraz Bank Światowy, a podejmowane inicjatywy wykraczają swoim zasięgiem poza kraje Europy. W polityce Unii działania na rzecz klastrów stanowią element polityki innowacyjnej, a najważniejsze decyzje związane z ich kształtem leżą w gestii poszczególnych krajów członkowskich. Polityka rozwoju oparta na klastrach realizowana jest na trzech zasadniczych poziomach, tj. na szczeblu instytucji europejskich (obejmuje działania inicjowane przez Komisję oraz Europejski Bank Inwestycyjny), na poziomie krajów członkowskich w ramach różnych wspólnych polityk, a także strategii krajowych poszczególnych państw.

Celem opracowania jest przedstawienie polityki klastrowej realizowanej na poziomie Unii Europejskiej w latach 2006-2020. Uwaga autora skupiona została na działaniach podejmowanych przez Komisję Europejską (KE). W pierwszej części artykułu przybliżono istotę i wybrane modele polityki klastrowej. Następnie przedstawiono zapisy najważniejszych oficjalnych dokumentów Unii Europejskiej odnoszące się do gron. W dalszej kolejności zaprezentowano wybrane działania i inicjatywy Komisji na rzecz wspierania struktur klastrowych podejmowane w latach 2006-2014, a także założenia przyjęte $\mathrm{w}$ tym zakresie na bieżący okres programowania. $\mathrm{W}$ zakończeniu, w nawiązaniu do prowadzonych rozważań, przedstawiono wnioski oraz dokonano podsumowania aktywności Komisji w zakresie wspierania gron.

\section{Pojęcie i rodzaje polityki klastrowej}

Polityka klastrowa rozumiana jest najszerzej jako koncepcja rozwoju kraju lub regionu bazująca na gronach, łącząca wiele różnych strategii i instrumentów, które w sposób skoordynowany wspierają rozwój tych struktur. Występują również pro-

${ }^{1}$ Przedmiotem analizy w poniższym opracowaniu są klastry/grona określane przez M.E. Portera, jako ,geograficzne skupiska wzajemnie powiązanych firm, wyspecjalizowanych dostawców, jednostek świadczących usługi, firm działających w pokrewnych sektorach i związanych z nimi instytucji (np. uniwersytetów, jednostek normalizacyjnych i stowarzyszeń branżowych) w poszczególnych dziedzinach, konkurujących między sobą, ale także współpracujących" [Porter 2000]. 
gramy dla klastrów, tj. zbiory założeń, działań i narzędzi ukierunkowanych na wspieranie rozwoju gron na określonym terytorium [Dzierżanowski (red.) 2012, s. 16].

W zależności od stawianych celów polityka wspierania klastrów może przybierać różne formy. Pierwsza, najbardziej horyzontalna kategoria dotyczy strategii ukierunkowanej na tworzenie korzystnych mikroekonomicznych warunków otoczenia biznesowego na rzecz wzrostu gospodarczego i innowacji, co w pośredni sposób stymuluje powstanie i rozwój gron. Drugi rodzaj obejmuje tradycyjne polityki przemysłowe, dotyczące sektora MŚP, badawcze oraz regionalne, które często wykorzystują koncepcję klastrów dla zwiększenia efektywności konkretnego instrumentu wsparcia. Na trzecią kategorię składają się programy rozwojowe, których celem jest utworzenie, mobilizacja lub wzmocnienie danego rodzaju gron, co skutkuje powstaniem poszczególnych inicjatyw klastrowych ${ }^{2}$ [The concept... 2008, s. 32].

W literaturze przedmiotu wymienia się kilka modeli polityki klastrowej, odnoszących się przede wszystkim do działań podejmowanych na poziomie krajowym, regionalnym lub lokalnym. KE wskazuje na dwa zasadnicze modele. Pierwszy zakłada wspieranie koordynatorów klastrów, których funkcjonowanie przynosi wymierne korzyści jego aktorom. Ważnym celem jest także wspieranie powiązań typowych dla gron. Polityki skoncentrowane na wzmacnianiu relacji skupiają się na stymulowaniu i rozwijaniu wszelkiego typu współpracy między podmiotami gospodarczymi w ramach klastra, a także jego otoczenia, zarówno $\mathrm{w}$ sferze $\mathrm{B}+\mathrm{R}$, jak i w ramach relacji zachodzących w łańcuchu wartości oraz powiązań o charakterze horyzontalnym. Drugi model przewiduje wspieranie konkretnych przedsięwzięć realizowanych przez podmioty grona. Wspierane inicjatywy mają charakter jednostkowy (np. wspólne projekty B+R) i horyzontalny (np. budowa wspólnej infrastruktury badawczej) [Dzierżanowski i in. 2012, s. 9; European... 2003, s. 4].

Polityka wspierania gron może mieć charakter odgórny lub oddolny. W pierwszym przypadku istotną rolę odgrywa zaangażowanie władz publicznych, a wsparcie nastawione jest na rozwój konkretnych, selektywnie wybranych ${ }^{3}$, gron. Natomiast w podejściu oddolnym wspierane są klastry powstające niezależnie od władz publicznych. Istnieje również polityka hybrydowa, będąca połączeniem działań odgórnych i oddolnych [Brodzicki, Kuczewska (red.) 2012, s. 36, 38].

Polityka klastrowa formułowana jest na wszystkich szczeblach - od lokalnego, przez regionalny, centralny aż po szczebel ponadnarodowy. W zależności od poziomu, na którym jest realizowana, CBP powinna cechować horyzontalność i kompleksowość na szczeblu międzynarodowym i narodowym oraz decentralizacja i szczegółowość rozwiązań dopasowanych do specyfiki poziomu lokalnego i regionalnego [Oleksiuk 2009, s. 85; Sołdra-Gwiżdż, Bereś 2011, s. 21-22].

${ }^{2}$ Przez pojęcie inicjatywy klastrowej rozumie się ,,zorganizowane działania mające na celu intensyfikację wzrostu i konkurencyjności klastrów w regionie, angażujące firmy klastrowe, rząd oraz/lub środowisko badawcze" [Sölvell i in. 2003, s. 9].

${ }^{3}$ Wybranych odgórnie z uwagi na wielkość zatrudnienia potencjał innowacyjny, branże lub w wyniku konkursów. 
Na poziomach międzynarodowym i rządowym polityka klastrowa realizowana jest poprzez formułowanie strategii, wyznaczanie ogólnych kierunków rozwoju tzw. obszarów priorytetowych, jak również wsparcie finansowe realizowanych przedsięwzięć. Natomiast do zadań agencji szczebla narodowego oraz administracji samorządowej należy aktywne uczestnictwo w formułowaniu strategii na poziome regionalnym i lokalnym, a przede wszystkim wdrażanie polityki i zarządzanie programami realizującymi wyznaczone kierunki rozwoju [Warzybok 2008, s. 24].

\section{Klastry w oficjalnych dokumentach Unii Europejskiej}

Najważniejszym dokumentem odnoszącym się do gron jest komunikat Komisji z 2008 roku, dotyczący klastrów o znaczeniu światowym oraz wdrażaniu szeroko zakrojonej strategii w zakresie innowacji. Głównym celem jego wydania było nakreślenie ram polityki na rzecz lepszej komplementarności i synergii pomiędzy różnymi poziomami polityki klastrowej dla wspierania rozwoju większej liczby światowej klasy gron we Wspólnocie. W dokumencie zaproponowano powołanie Europejskiej Grupy ds. Polityki Klastrowej, odgrywającej rolę doradczą wobec Komisji i państw członkowskich w zakresie możliwych kierunków strategicznych tworzenia i rozwoju klastrów światowej klasy ${ }^{4}$. Przedstawiono propozycję utworzenia europejskiej inicjatywy pilotażowej na rzecz doskonałości organizacji klastrów - oferującej specyficzne programy szkoleniowe i zwiększoną współpracę menedżerom klastrów w celu stworzenia samofinansującego się, nienastawionego na zysk, europejskiego stowarzyszenia menedżerów klastrów, które opracowałoby i zarządzało europejskim znakiem jakości w celu doskonalenia organizacji gron. Ustanowienie tego wspólnotowego projektu związane było ze stworzeniem systemu ewaluacji inicjatyw klastrowych umożliwiającym kierowanie pomocy do najlepszych gron, mających szansę na skuteczną konkurencję w warunkach globalizacji, co zapewni racjonalne i efektywne wykorzystanie publicznych środków finansowych. Według przyjętych założeń głównymi celami działań podejmowanych na rzecz rozwoju gron było zwiększenie liczby klastrów na światowym poziomie, podniesienie ich potencjału innowacyjnego oraz internacjonalizacja. W komunikacie wskazano działania na rzecz opracowania i udoskonalania baz danych i map klastrów dla państw członkowskich w ramach Europejskiego Obserwatorium Klastrów (ECO) ${ }^{5}$. Zwrócono uwagę na znaczenie wspierania transgranicznej współpracy gron w UE, która może doprowadzić do silniejszych związków między różnymi podmiotami dysponującymi komplementarnymi umiejętnościami [Komunikat... 2008].

Koncepcja gron wpisuje się również w kluczowe priorytety strategii Europa 2020, które obejmują rozwój inteligentny, zrównoważony i sprzyjający włączeniu społecznemu oraz wspieranie gospodarki charakteryzującej się wysokim poziomem

\footnotetext{
${ }^{4}$ Grupa ta została powołana do życia w grudniu 2008.

${ }^{5}$ European Cluster Observatory (ECO).
} 
zatrudnienia, zapewniającej spójność gospodarczą, społeczną i terytorialną. Ważny element strategii stanowi koncepcja inteligentnej specjalizacji regionów, w którą wpisuje się idea wspierania klastrów. Temat gron podjęty został również w przedmiotowej strategii „Polityka przemysłowa w erze globalizacji”, w zakresie której Komisja podejmuje się m.in. poprawić otoczenie biznesu, szczególnie w odniesieniu do sektora MŚP, np. poprzez ograniczenie kosztów prowadzenia działalności gospodarczej w Europie, wspieranie klastrów i ułatwienie niedrogiego dostępu do finansowania [Europa 2020... 2010].

\section{Działania Komisji Europejskiej na rzecz wspierania klastrów podejmowane w latach 2006-2014}

Aktywności podejmowane na rzecz wspierania struktur klastrowych we Wspólnocie skupiają się na dwóch obszarach, tj. wzmacnianiu współpracy pomiędzy podmiotami gron oraz zarządzaniu klastrami.

Inicjatywą skupioną na kooperacji było przedsięwzięcie pn. Europe INNOVA', które w zakresie wspierania klastrów obejmowało analizy dotyczące innowacyjności w ramach $\mathrm{ECO}^{7}$ oraz Europejską Platformę Innowacji na rzecz Klastrów (Cluster-IP), której celem jest wsparcie rozwoju innowacji i wzrostu klastrów w Europie [http://www.cip.gov.pl/europe-innova].

Celem realizacji pierwszej fazy projektu (2006-2009) było: wspieranie współpracy między klastrami, umożliwienie im podjęcia dialogu, rozwijania, testowania i wymiany dobrych praktyk w celu wspierania innowacyjnych MŚP oraz przyczynianie się do lepszego zrozumienia wzorców innowacji w różnych sektorach. Wsparciem objętych zostało jedenaście sieciowych klastrów przemysłowych, skupionych wokół siedmiu branż, którym zapewniono dostęp do platformy, w ramach której mogły dzielić się dobrymi praktykami w zakresie zarządzania klastrami. Pomoc koncentrowała się przede wszystkim na wzmocnieniu regionalnych systemów innowacji oraz wspieraniu współpracy ponadnarodowej w celu dalszego przyspieszenia rozwoju tych klastrów tak, aby mogły stać się konkurencyjne w skali ogólnoeuropejskiej. Natomiast celem drugiej fazy realizacji inicjatywy (2009-2012) było wspieranie międzynarodowej współpracy pomiędzy sektorowymi inicjatywami klastrowymi. Podejmowano głównie działania związane z rozwojem Europejskiej Platformy Innowacji na rzecz Klastrów, której zadaniem było wspieranie przedsiębiorstw, przede wszystkim tych z sektora MŚP, w umiędzynarodowieniu działalności gospo-

${ }^{6}$ Realizowane w ramach Programu Ramowego na rzecz Konkurencyjności i Innowacji, ustanowionego na lata 2007-2013, który stał się główną podstawą prawną wszelkich działań wspólnotowych w dziedzinie innowacji i konkurencyjności.

${ }^{7}$ ECO zajmuje się mapowaniem gron na poziomie krajowym i regionalnym, a także przeglądem polityk i programów na rzecz klastrów w celu utworzenia europejskiej bazy danych o gronach przy użyciu tej samej metodologii oraz dostarczaniem narzędzi umożliwiających porównanie działania klastrów w całej Europie. 
darczej oraz rozwijaniu partnerstwa z przedsiębiorstwami i instytucjami badawczymi spoza regionu [Evaluation... 2014].

Przykładem aktywności w dziedzinie umiędzynarodowiania klastrów był również Europejski Alians Klastrów (ECA) ${ }^{8}$. Inicjatywa założona została przez partnerów uczestniczących w czterech politycznych projektach klastrowych, znanych jako sieci $\mathrm{INNO}^{9}$, finansowanych w ramach inicjatywy PRO INNO Europe. Projekty te realizowane były w latach 2006-2009 w ramach 6. Programu Ramowego „Badania naukowe i innowacje". ECA to otwarta platforma założona w celu utrzymania stałego dialogu politycznego na szczeblu UE wśród krajowych i regionalnych władz publicznych odpowiedzialnych za rozwój polityki klastrowej i zarządzanie lub finansowanie programów klastrowych w swoich krajach lub regionach [http://www. eca-tactics.eu/eca]. ECA zajmowało się m.in. internacjonalizacją MŚP w ramach gron oraz analizą różnych narzędzi i instrumentów wykorzystywanych dla realizacji polityki klastrowej, jak również odziaływaniem polityk i inicjatyw klastrowych. Działania stowarzyszenia obejmowały również prace nad zapewnieniem lepszych warunków ramowych do powstania większej liczby światowej klasy gron w UE [Izsak 2008]. Zasadniczym zadaniem tego przedsięwzięcia była harmonizacja wysiłków regionalnych, wymiana doświadczeń, eliminowanie barier współpracy klastrów oraz wspieranie rozwoju wspólnych działań pomiędzy regionami europejskimi [Kowalski 2008, s.17; http://www.eca-tactics.eu/eca].

Od stycznia 2010 roku ECA zarządzany był w ramach nowego projektu klastrowego INNO-Net o nazwie TACTICS, finansowanego przez Dyrekcję Generalną ds. Przemysłu i Przedsiębiorczości, a prowadzony przez OSEO (Francja) we współpracy z sześcioma innymi agencjami innowacji [http://www.eca-tactics.eu/eca]. Projekt miał na celu wspieranie i dalsze rozwijanie ECA oraz wypracowanie rekomendacji na rzecz ulepszenia polityki klastrowej i praktycznych narzędzi jej wdrażania w Europie. Program był realizowany przez siedem czołowych organizacji krajowych i regionalnych zajmujących się innowacjami oraz polityką klastrową, które wspierała grupa złożona z zewnętrznych ekspertów. Realizowano go w ramach sześciu zespołów zadaniowych, w których przeanalizowano aktualne i proponowane działania w zakresie polityki klastrowej. Zespoły sformułowały również konkretne zalecenia w obszarach tematycznych istotnych z punktu widzenia klastrów, takich jak: wspieranie współpracy międzynarodowej, finansowanie badań, rozwoju i innowacji poprzez klastry doskonałe, wykorzystanie gron do wspierania innowacji sterowanych przez użytkowników, marketing i budowa marki klastra, wykorzystanie gron do wspierania nowo powstających branż i innowacyjnych usług [Cluster... 2012].

Najważniejsze działania w zakresie zarządzania klastrami rozpoczęto w roku 2009 trzyletnim projektem pn. Europejska Inicjatywa na rzecz Doskonałości Klastrów (ECEI) ${ }^{10}$, którego celem było podniesienie poziomu doskonałości gron i zarzą-

\footnotetext{
${ }^{8}$ European Cluster Alliance (ECA).

9 Były to następujące projekty: BSR InnoNet, CEE-Cluster Network, CLUNET i INNET.

${ }^{10}$ European Cluster Excellence Initiative (ECEI).
} 
dzania sieciami w UE, a także promowanie profesjonalnych praktyk zarządzania. Efektem projektu, który zgromadził trzynastu partnerów z dziewięciu krajów, było opracowanie narzędzi benchmarkingu oraz znaku jakości dla profesjonalnego zarządzania gronami [Evaluation... 2014] ${ }^{11}$. W ramach przedsięwzięcia sfinansowano platformę internetową pn. Europejska Platforma Współpracy Klastrów (ECCP) ${ }^{12}$, której zadaniem jest stymulowanie transnarodowej i międzynarodowej współpracy między klastrami. Platforma jest otwarta dla menedżerów i koordynatorów klastrów oraz podmiotów należących do gron, a użytkownicy uzyskują szereg korzyści wynikających z dostępu do informacji i baz danych oraz wsparcia współpracy pomiędzy gronami i organizacjami klastrowymi. W ramach projektu podejmowano także działania mające na celu rozwój systemu profesjonalnych szkoleń dla menedżerów klastrów ${ }^{13}$ [www.pi.gov.pl; http://www.clustercollaboration.eu/].

\section{Założenia odnoszące się do wspierania klastrów w Unii Europejskiej w latach 2014-2020}

W nowej perspektywie finansowej Komisja Europejska wspiera rozwój klastrów, które ze względu na swoją naturę odgrywają ważną rolę w ewolucji i transformacji europejskiego przemysłu w kierunku nowych strategicznych specjalizacji. Strategia wspierania gron na lata 2014-2020 zakłada [Klastry... (13.03.2014); Polityka... (27.09.2016)]:

- Podnoszenie jakości zarządzania gronami i usprawnienie procesów zarządczych w organizacjach klastrowych, rozwijanie kompetencji menedżerów.

- Internacjonalizację współpracy pomiędzy klastrami w Europie i poza nią.

- Rozwijanie kooperacji międzysektorowej i powstanie nowych przemysłów.

- Angażowanie gron w procesy określania i wdrażania inteligentnych specjalizacji.

- Lepsze wykorzystanie klastrów dla rozwijania MŚP.

Działania skupione na zarządzaniu klastrami realizowane są poprzez szkolenia oraz certyfikację jakości. Szkolenia skierowane zarówno do menedżerów, jak i trenerów gron organizowane są przez EFQM, w oparciu o metodologię opracowaną w ramach inicjatywy ECEI [http://www.clusterexcellence.org].

Natomiast dla potwierdzenia stopnia jakości w zarządzaniu grona mogą ubiegać się o brązowe, srebrne albo złote odznaki, które przyznawane są przez ESCA w oparciu o metodę benchmarkingu względem najlepszych klastrów w danej klasie, a także względem klastrów europejskich i pozaeuropejskich. Zadaniem instytucji jest nie

${ }^{11}$ System oznakowania jakości gron obsługiwany jest przez Europejski Sekretariat Analizy Klastrów (European Secretariat for Cluster Analysis - ESCA).

${ }_{12}$ European Cluster Collaboration Platform (ECCP).

${ }^{13}$ Od 2012 roku pieczę nad systemem szkoleń sprawuje Europejska Fundacja na rzecz Klastrów i Konkurencyjności (European Foundation for Quality Management - EFQM). 
Alina Piątyszek-Pych

tylko przyznawanie znaku jakości, ale także stałe doskonalenie i bieżące uaktualnianie narzędzi wykorzystywanych $\mathrm{w}$ benchmarkingu [http://www.cluster-analysis. org].

Natomiast umiędzynarodowienie kooperacji gron i firm je tworzących realizowane jest poprzez porozumienia z zagranicznymi partnerami oraz misje gospodarcze. Porozumienia podpisywane są między ECCP a partnerami zagranicznymi spoza Europy. Komisja pracuje także nad odnowieniem strony i narzędzi sieciowych, aby zapewnić użytkownikom platformy ECCP jak największą wartość. Organizuje także cyklicznie misje gospodarcze dla przedstawicieli organizacji zarządzających klastrami oraz dla MŚP działających w gronach dla krajów, z którymi podpisano porozumienia o współpracy. Misje mają na celu internacjonalizację firm poprzez klastry i stanowią okazję do znalezienia partnerów technologicznych i biznesowych, jak również do wejścia na zagraniczne rynki. Nawiązana współpraca międzynarodowa ma przyczynić się do zwiększenia innowacyjności i konkurencyjności klastrów i firm w skali globalnej [Klastry... (13.03.2016); European... (27.09.2016)].

Narzędziem wspierania współpracy międzynarodowej są także Europejskie Strategiczne Partnerstwa Klastrów (ESCP) ${ }^{14}$, których celem jest współpraca gron i sieci przekraczająca granice geograficzne i sektorowe, która ma przyczynić się do powstania nowych łańcuchów wartości obejmujących firmy z różnych sektorów, jak również zapewnić lepsze wsparcie MŚP w warunkach konkurencji globalnej [Polityka... (27.09.2016)]. ESCP promowane są do prowadzenia współpracy międzynarodowej klastrów w nowych dziedzinach, w szczególności w celu wsparcia wschodzących gałęzi przemysłu [http://www.clustercollaboration.eu].

W nowej perspektywie finansowej Komisja promuje także współpracę pomiędzy gronami i przedsiębiorstwami reprezentującymi różne przemysły. Realizacja działań w tym zakresie odbywa się poprzez [Polityka... (27.09.2016)]:

- analizy poświęcone nowo powstającym branżom i narzędziom do mapowania klastrów w nowych sektorach,

- wsparcie tworzenia innowacji międzysektorowych i innowacji związanych z nowymi łańcuchami wartości przy wykorzystaniu klastrów,

- wsparcie testowania narzędzi i instrumentów polityki klastrowej w odniesieniu do nowo powstających branż,

- wsparcie wzajemnego uczenia się,

- dostarczanie informacji na temat europejskich inicjatyw, które wspierają powstawanie nowych przemysłów.

${ }^{14}$ European Strategic Cluster Partnerships (ESCP) utworzone zostały w związku z realizacją w latach 2012-2014 inicjatywy pn. „Promocja i rozwój światowej klasy klastrów w Europie”, której celem było: opracowanie wspólnych strategii internacjonalizacji wśród europejskich klastrów w poszczególnych sektorach na rzecz MŚP, kształtowanie strategicznych sojuszy w zakresie wspólnego wchodzenia na rynek międzynarodowy, weryfikacja narzędzi benchmarkingu i materiałów szkoleniowych powstałych w ramach ECEI, a także promowanie współpracy między klastrami [Evaluation... 2014]. 
Realizacja europejskiej strategii wspierania klastrów odbywa się przy wykorzystaniu środków programu ramowego COSAME, w ramach którego wdrażane są dwa programy dla gron, tj. program doskonalenia klastrów (obejmuje finansowanie benchmarkingu i szkoleń dla organizacji klastrowych i menedżerów) oraz program internacjonalizacji klastrów na rzecz MŚP (wspiera m.in. działanie Cluster Go International, które ma na celu tworzenie i rozwijanie ESCP) [European... (27.09.2016)]. Pomoc dla gron uwzględniono także w programie ramowym badań i rozwoju HORIZONT 2020, który wspiera projekty demonstracyjne z udziałem klastrów na rzecz nowych przemysłowych łańcuchów wartości (emerging industries).

\section{Zakończenie}

Unia Europejska od wielu lat przywiązuje dużą wagę do rozwoju klastrów, uważając je za motory rozwoju gospodarczego. Udzielanie pomocy inicjatywom klastrowym w Europie ma na celu zwiększenie liczby klastrów na światowym poziomie, podniesienie ich potencjału innowacyjnego oraz udoskonalenie międzynarodowej współpracy w obszarze klasteringu. Kluczowe decyzje dotyczące kształtu i sposobów realizacji CBP leżą w kompetencji poszczególnych państw członkowskich. Rolą Wspólnoty jest ułatwienie i wspieranie tych wysiłków poprzez poprawę warunków ramowych, promowanie doskonałości i przedsiębiorczości w zakresie badań i edukacji, tworzenie silniejszych relacji pomiędzy przedsiębiorstwami a podmiotami sfery $\mathrm{B}+\mathrm{R}$, jak również mobilizowanie do wymiany wiedzy na temat form polityki klastrowej i kooperacji gron w UE. Komisja Europejska prowadzi nie tylko regularne obserwacje inicjatyw na rzecz wspierania klastrów, lecz również dokonuje analiz porównawczych zidentyfikowanych gron w skali całej Unii. Aktywność KE polega również na tworzeniu korzystnych ram regulacyjnych, popularyzacji koncepcji klastra i wymiany wiedzy oraz opracowywaniu zaleceń dla władz publicznych dotyczących właściwego wspierania procesu klasteringu. Poza pełnieniem roli katalizatora Komisja podejmuje także bezpośrednie działania na rzecz wspierania rozwoju gron we Wspólnocie poprzez uruchamianie i finansowanie coraz liczniejszych inicjatyw i programów, a także europejskich platform technologicznych.

Aktywności KE podejmowane na rzecz wspierania struktur klastrowych skupiają się na dwóch obszarach, tj. wzmacnianiu współpracy pomiędzy podmiotami gron oraz zarządzaniu klastrami. Inicjatywy te można podzielić na dwie zasadnicze generacje. Działania należące do pierwszej z nich rozpoczęto już w latach 2006-2014 i koncentrują się one na analizie rozwoju klastrów w Europie przy wykorzystaniu ECO. Polegają na opracowywaniu wspólnej metodologii badania gron, promowaniu najlepszych technik analizy, wypracowaniu rekomendacji dla właściwego kształtowania polityki wspierania i zarządzania inicjatywami klastrowymi. Dotyczą także kooperacji transnarodowej pomiędzy klastrami (Europe INNOVA). Inicjatywy drugiej generacji, będące kontynuacją działań podejmowanych w poprzednim okresie finansowania, mają na celu zbadanie roli klastrów w rozwoju branż wschodzących, 
tzw. nowych przemysłów (emerging industries), a także wypracowanie skuteczniejszych sposobów wzmocnienia zarządzania klastrami oraz profesjonalizację wsparcia gron (cluster excellence initiatives). Generacja ta obejmuje aktywności mające na celu dostarczenie najwyższej klasy usług niestandardowych dla MŚP oraz wspieranie międzynarodowej współpracy struktur klastrowych (cluster internationalisation initiatives), a także włączenie gron w proces określania inteligentnych specjalizacji.

Bezpośrednie działania na rzecz klastrów przyniosły realne efekty. Na przykład w zakresie inicjatywy Europa INNOVA funkcjonuje Europejska Sieć Strategii Motoryzacyjnych, która angażuje 45 regionów europejskich. Celem jej funkcjonowania jest integrowanie działań w sektorze automotive w krajach UE. W ramach projektu Europe INNOVA wielokrotnie dokonano mapowania i badania klastrów w UE, a ECO dostarcza decydentom informacji na temat polityki wspierania gron i potencjału klastrów. Na obecnym etapie brakuje jednak niepodważalnych dowodów potwierdzających efektywność polityki klastrowej, które miałyby charakter przekrojowy, a nie były oparte na studiach przypadków wybranych spośród efektywnie działających klastrów. Potrzebne są także pogłębione analizy gron na poziomie mikro oraz ewaluacje wpływu polityki na produktywności firm. Natomiast dzięki realizacji inicjatywy PRO INNO Europe powstały 4 sieci klastrów na poziomie politycznym. Skutkiem realizacji przedsięwzięcia ECEI było wypracowanie jednolitych dla całego obszaru Wspólnoty wskaźników zarządzania klastrami.

Analiza działań podejmowanych przez Komisję pozwala na wysunięcie wniosku, że w pełni akceptuje ona sterowany przez rynek charakter klastrów, propagując podejście oddolne w ich wspieraniu (z dominującą rolą sektora prywatnego i administracji jako katalizatora zmian), polegające na podejmowaniu aktywności na rzecz rozwoju gron, a nie ich budowaniu od podstaw. Doświadczenia potwierdzają, że próby odgórnego tworzenia tych struktur kończą się niepowodzeniem w sytuacji, gdy brakuje endogenicznego potencjału bazowego. Działania KE odnoszą się do rozwiniętych innowacyjnych klastrów transnarodowych, marginalizuje się natomiast wagę gron regionalnych i działających w sektorach tradycyjnych. Związane jest to z przyjmowaną przez Komisję zasadą koncentracji środków publicznych na najbardziej konkurencyjnych klastrach, mających szansę skutecznie konkurować w warunkach gospodarki globalnej. Uzasadnieniem dla tak prowadzonej polityki jest fakt, że mimo działań na rzecz likwidowania barier w handlu i mobilności w UE, klastry nie zawsze dysponują niezbędną masą krytyczną i zdolnością do innowacji. Grona europejskie mogą zrekompensować niektóre $\mathrm{z}$ tych wad, tworząc silniejsze związki z innymi klastrami dysponującymi komplementarnymi umiejętnościami. Stwarza to jednak niebezpieczeństwo, że zaproponowane rozwiązania ograniczą możliwość wspierania mniej rozwiniętych inicjatyw, dominujących w krajach, w których klastering znajduje się w początkowym etapie rozwoju. Należy mieć także na względzie fakt, że nie wszystkie grona mogą osiągać ten sam poziom rozwoju lub mieć podobny zasięg międzynarodowy i że nie wszystkie struktury klastrowe działają w sektorach o wysokim poziomie technologii. 
Działania Komisji skierowane są przede wszystkim do dojrzałych struktur klastrowych. Natomiast doświadczenia światowe pokazują, że warto wspierać grona na wszystkich etapach ich rozwoju, wykorzystując jednak różne narzędzia i instrumenty. CBP promowana przez KE skierowana jest przede wszystkim do inicjatyw klastrowych. Może to doprowadzić do sytuacji, w której udzielenie wsparcia publicznego prężnym gronom, które nie sformalizowały współpracy, będzie bardzo ograniczone. Tak prowadzona polityka może się przyczynić do powstawania nowych, sztucznych inicjatyw, o małym potencjale rynkowym, które powołane zostaną jedynie w celu możliwości pozyskiwania środków finansowych. Ponieważ grona stanowią środowisko sprzyjające tworzeniu związków małych i średnich przedsiębiorstw z sektorem B+R i innymi podmiotami gospodarczymi, a także umożliwiają im dostęp do międzynarodowych sieci handlowych, wspieranie klastrów w Europie jest także częścią polityki sektora MŚP. Należy jednak pamiętać, że niektóre kraje i regiony koncentrują się nadmiernie na tym sektorze, pomijając fakt, że niedostateczna obecność dużych przedsiębiorstw może ograniczyć wpływ gospodarczy klastrów.

KE zachęca państwa członkowskie do harmonizacji i integracji kryteriów wspierania klastrów na szczeblu europejskim, w celu stworzenia jednolitej wizji zorganizowanego działania. Koncepcja europejskiej polityki klastrowej zmierza w kierunku rozwijania dużych międzynarodowych klastrów o wysokim stopniu innowacyjności. $\mathrm{O}$ ile będzie to korzystane z punktu widzenia rynku europejskiego, o tyle w przypadku poszczególnych państw członkowskich może to być trudne do zrealizowania. Wynika to $\mathrm{z}$ faktu, że w wielu krajach funkcjonują grona znajdujące się w początkowym okresie rozwoju, o niższym poziomie innowacyjności i umiędzynarodowiania działalności. Z uwagi na dużą heterogeniczność klastrów, a co za tym idzie zróżnicowanie determinant ich rozwoju, zasada jednolitej wizji wspierania tych struktur nie jest możliwa do praktycznej implementacji. Lepszym rozwiązaniem jest regionalizacja, a nawet lokalizacja polityki klastrowej. Europejskie inicjatywy wspierające grona powinny być także komplementarne wobec regionalnych i narodowych działań, tak aby lepiej wykorzystywać synergię i wspierać określone priorytety tych państw. Z drugiej strony, regiony i państwa członkowskie powinny w pełni wykorzystywać, dostępny na poziomie europejskim, potencjał finansowy w celu wzmocnienia swoich klastrów i ich otwarcia na międzynarodową współpracę.

Mimo zastrzeżeń odnośnie do koncepcji europejskiej polityki klastrowej można wysunąć wniosek, że podejmowane działania przyniosły wymierne korzyści. Wskazać można coraz większą liczbę przypadków, w których wybiegająca w przyszłość polityka publiczna, inicjatywy przedsiębiorstw oraz wysokiej jakości instytucji $\mathrm{B}+\mathrm{R}$ doprowadziły do powstania silnych klastrów, gdyż działały one jak katalizatory i pomagały uwolnić gospodarczy i naukowy potencjał regionów. Skutecznie wdrażana polityka w znacznym stopniu zmniejszyła przeszkody rozwoju gron. W sposób szczególny KE eliminuje bariery rynkowe poprzez podejmowanie działań na rzecz swobodnego przepływu czynników produkcji, poprawę spójności polityki innowacyjnej, tworzenie sprzyjającym innowacjom ram legislacyjnych oraz dystrybucję 
środków, które umożliwią realizację przedsięwzięć dedykowanych gronom (przede wszystkim podnoszenia poziomu ich innowacyjności). Szczególnie ważną rolę odgrywają środki przeznaczone na badania i rozwój, które pozwalają na podnoszenie poziomi innowacyjności gospodarek narodowych i reformację sektora B+R. Inicjatywy KE przyczyniają się także do ograniczenia barier organizacyjnych, do których należą słabe powiązania pomiędzy podmiotami życia gospodarczego oraz niewielka współpraca przedsiębiorstw ze sferą $\mathrm{B}+\mathrm{R}$. Działania KE nie są jednak w stanie zmniejszyć ograniczeń mentalnych, utożsamianych z czynnikami społeczno-kulturowymi, zakorzenionymi zasadami współpracy oraz deficytem zaufania w sferze publicznej. W tym obszarze ważną rolę odrywać powinny władze lokalne i regionalne oraz wyspecjalizowane agencje konsultingowe, których zadaniem jest animowanie współpracy w regionie, a także przeprowadzenie bardzo szerokiej kampanii informacyjnej na temat korzyści współpracy. Bazą dla tych działań mogą być przykłady dobrych praktyk prezentowane przez Europejskie Obserwatorium Klastrów.

\section{Literatura}

Brodzicki T., Kuczewska J. (red.), 2012, Klastry i polityka klastrowa w Polsce. Konkurencyjność przedsiębiorstw, sektorów i regionów, Wydawnictwo Uniwersytetu Gdańskiego, Gdańsk.

Cluster internationalization - handbook, 2012, TACTICS Manchester Metropolitan University.

Dzierżanowski M. (red.), 2012, Kierunki i założenia polityki klastrowej w Polsce do 2020 roku - rekomendacje grupy roboczej ds. polityki klastrowej, Polska Agencja Rozwoju Przedsiębiorczości, Warszawa.

Dzierżanowski M., Rybacka M., Szultka S., 2012, Rola klastrów w budowaniu gospodarki opartej na wiedzy, Urząd Marszałkowski Województwa Zachodniopomorskiego, Gdańsk - Szczecin.

Europa 2020. Strategia na rzecz inteligentnego i zrównoważonego rozwoju sprzyjającego włączeniu społecznemu, 2010, Bruksela.

European Trend Chart on Innovation Thematic Report Cluster Policies, 2003, European Commission Enterprise Directorate-General.

European Union Cluster Portal, http://ec.europa.eu/growth/smes/cluster_en (27.09.2016).

Evaluation Cluster initiatives managed by DG Enterprise and Industry, 2014, Flora Giarracca and Alasdair Reid (Technopolis Group), Brussels.

http://www.cip.gov.pl/europe-innova (13.07.2012).

http://www.cluster-analysis.org (27.09.2016).

http://www.clustercollaboration.eu/ (27.09.2016).

http://www.clusterexcellence.org/ (27.09.2016).

http://www.eca-tactics.eu/eca (13.07.2012).

Izsak K., 2008, Naprzeciw klastrom o znaczeniu światowym w Unii Europejskiej, [w:] Dzierżanowski M., Szultka S. (red.), Wspieranie rozwoju klastrów w Polsce i za granica, Instytut Badań nad Gospodarką Rynkową, Gdańsk.

Klastry w Unii Europejskiej w nowej perspektywie finansowej 2014-2020, www.pi.gov.pl (13.03.2016).

Komunikat Komisji do Rady, Parlamentu Europejskiego, Europejskiego komitetu Ekonomiczno-Społecznego i Komitetu Regionów. W kierunku światowej klasy klastrów w Unii Europejskiej: wdrażanie szeroko zakrojonej strategii innowacyjnej, $\operatorname{KOM(2008)~} 652$. 
Kowalski M.A., 2008, Instytucjonalno-prawne aspekty polityki innowacyjnej na poziomie regionalnym, Instytut Gospodarki Światowej SGH, Warszawa.

Oleksiuk A., 2009, Konkurencyjność regionów a parki technologiczne i klastry przemysłowe, Oficyna Wydawnicza Branta, Bydgoszcz - Warszawa.

Polityka klastrowa w Unii Europejskiej, www.pi.gov.pl (27.09.2016).

Porter M.E., 2000, Location, competition and economic development: local clusters in a global econo$m y$, Economic Development Quarterly, vol. 14, no. 1, s. 15-34.

Sölvell O., Lindqvist G., Ketels C.H., 2003, The Cluster Initiative Greenbook, Harvard Business School, Stockholm.

Sołdra-Gwiżdż T., Bereś A., 2011, Sektor B+R i otoczenia biznesu a rozwój klastrów w województwie opolskim - badania FGI, [w:] Duczmal W., Potwora W. (red.), Strefa B+R i otoczenia biznesu a rozwój klastrów w województwie opolskim. Seria: Klastry i inicjatywy klastrowe w województwie opolskim, t. 7, Wyższa Szkoła Zarządzania i Administracji w Opolu, Opole.

The concept of clusters and cluster policies and their role for competitiveness and innovation: main statistical results and lessons learned, 2008, Europe INNOVA / PRO INNO Europe Paper no. 9.

www.pi.gov.pl (16.04.2012).

Warzybok B., 2008, Przykłady zagranicznych instrumentów i kierunków wsparcia gron przedsiębiorczości oraz identyfikacja dotychczasowych kierunków wspierania inicjatyw klastrowych, [w:] Stawicki M., Pander W. (red.), Metody ewaluacji polityk wspierania klastrów z funduszy strukturalnych, Szkoła Główna Gospodarstwa Wiejskiego, Warszawa. 